(C) Wilkinson K, 'Is this the Future We Want? An Ecofeminist Comment on the UN Conference on Sustainable Development Outcome Document' in K Rubenstein and KG Young (eds), The Public Law of Gender: From the Local to the Global (Cambridge University Press 2016).

DOI: https://doi.org/10.1017/cbo9781316481493.024

\title{
Is this the future we want? An ecofeminist comment on the UN Conference on
} Sustainable Development Outcome Document

\author{
Kate Wilkinson
}

22/11/2018 16:56:00

\section{Introduction}

In 2012, Governments and people from across the globe reconvened in Rio de Janeiro for the UN Conference on Sustainable Development (UNCSD), ${ }^{1}$ twenty years after the landmark UN Conference on the Environment and Development (UNCED). ${ }^{2}$ This conference was part of a long political process to refine and implement the concept of sustainable development, so as to achieve the interrelated policy aims of environmental sustainability and socio-economic development. At the UNCSD, Governments met with one main objective: to secure renewed political commitment for sustainable development. ${ }^{3}$ In order to achieve this, Governments agreed to discuss three thematic areas in the context of sustainable development and poverty eradication. Two of these themes considered the green economy in the context of the latter and an institutional framework for sustainable development. ${ }^{4}$ The Conference resulted in a political Outcome Document, entitled the 'The Future We Want' ${ }^{5}$ which compiled the views, aspirations and objectives of Governments to achieve sustainable development.

This chapter will examine the Outcome Document and its incorporation of the green economy. This is because the preparatory process for the UNCSD, the conference itself and the resulting Outcome Document have received mixed reactions, particularly from civil society activists such as ecofeminists and women's NGOs with a focus on environment/development associations. By examining the Outcome Document, I will explain the extent to which this text and the incorporated aims, affirmations and objectives may have moved the concept of

\footnotetext{
* The author wishes to express her greatest thanks to the editors, anonymous reviewers and fellow conference participants for their insightful suggestions in the numerous revisions of this chapter. The author also acknowledges the AHRC PhD Studentship and travel grant from the University of Sheffield which has made this contribution possible.

${ }^{1}$ Report of the United Nations Conference on Sustainable Development, UN Doc A/CONF.216/16 (2012).

${ }^{2}$ See Report of the United Nations Conference on Environment and Development, UN Doc A/CONF.151/26 (1992).

${ }^{3}$ Implementation of Agenda 21, the Programme for the Further Implementation of Agenda 21 and the Outcomes of the World Summit on Sustainable Development, GA Res 64/236, UN GOAR, $64^{\text {th }}$ Sess, Agenda Item 53(a), [20a], UN Doc A/RES64/236 (2009).

${ }^{4}$ Ibid.

${ }^{5}$ The Future We Want, GA Res 66/288, UNGAOR, 66 ${ }^{\text {th }}$ Sess, Agenda Item 19, UN Doc A/RES/66/288 (2012). .
} 
(C) Wilkinson K, 'Is this the Future We Want? An Ecofeminist Comment on the UN Conference on Sustainable Development Outcome Document' in K Rubenstein and KG Young (eds), The Public Law of Gender: From the Local to the Global (Cambridge University Press 2016).

DOI: https://doi.org/10.1017/cbo9781316481493.024

sustainable development, and the introduction of the green economy beyond the dominant social paradigm that has been roundly criticised by feminists for helping to maintain gender inequality.

\section{The UN Conference on Sustainable Development}

Prior to the UNCSD, the preparatory committee sought input from Member States and relevant stakeholders during the Outcome Document's development. ${ }^{6}$ The UNCSD Bureau compiled all contributions by Member States and relevant stakeholders, ${ }^{7}$ and refined them into a 'Zero Draft' of the Outcome Document. This provided the basis of the negotiations by Governments during the latter stages of the preparatory conferences and at the UNCSD itself. ${ }^{8}$ States negotiated and agreed the final text of the Outcome Document during the UNCSD, which was adopted by the UN General Assembly as Resolution 66/288.

The significant participation by the Major Groups during the UNCSD is a continuation of civil society participation in the achievement of sustainable development goals and principles, such as gender equality. ${ }^{9}$ The Women's Major Group (WMG) is a key actor concerned with gender

\footnotetext{
${ }^{6}$ Organizational and Procedural Matters, Note by the Secretariat, Preparatory Comm for the UN Conference on Sustainable Development, $1^{\text {st }}$ Sess, Agenda Item 4, [13-17], UN Doc A/CONF.216/PC/3 (2010); ,Report of the Preparatory Committee for the United Nations Conference on Sustainable Development, Preparatory Comm for the UN Conference on Sustainable Development, $2^{\text {nd }}$ Sess, [74], UN Doc A/CONF.216/PC/9 (2011).

7,Report of the Preparatory Committee, above n 6, [75]; Implementation of Agenda 21, the Programme for the Further Implementation of Agenda 21 and the outcomes of the World Summit on Sustainable Development, GA Res 66/197, UNGAOR, 66 ${ }^{\text {th }}$ Sess, Agenda Item 19(a), [2], UN Doc A/RES/66/197 (2011). The UNGA endorsed the process for preparing the draft outcome document.

${ }^{8}$ United Nations, Report of the Preparatory Committee, above n 6, [75].

${ }^{9}$ Implementation of Agenda 21 (2009), above n 3, [12], [15], [21-22]; Implementation of Agenda 21 (2011), above $\mathrm{n} 7$, , Annex II, [19-22]. Civil society participation has been increasingly prominent in environment and development Conferences since the UN Conference on Environment and Development (UNCED). Agenda 21: Programme of Action for Sustainable Development (1992) introduced the nine Major Groups who represent the interests of different sectors of society at international negotiations. A number of international agreements and declarations have actively supported gender equality as a pre-requisite to sustainable development. These include the Millennium development goals and the Beijing Platform of Action. See Report of the United Nations Conference on Environment and Development: Rio Declaration on Environment and Development, UN GAOR, Annex I, UN Doc. A/CONF.151/26 (Vol I) (1992); Report of the United Nations Conference on Environment and Development: Agenda 21, UN GAOR, Annex II, UN Doc A/CONF.151/26 (Vol I-III) (1992); Report of the World Summit on Sustainable Development: Plan of Implementation of the World Summit on Sustainable Development, Resolution II, Annex, UN Doc A/CONF.199/20 (2002); United Nations Millennium Declaration, GA Res 55/2, UN GAOR 55 ${ }^{\text {th }}$ Sess, Agenda Item 60(b), UN Doc A/RES/55/2 (2000); Beijing Declaration and Platform for Action: Report of the Fourth World Conference on Women, [4], UN Doc A/CONF.177/20 and UN Doc A/CONF.177/20/Add.1 (1995).See also The Convention on the Elimination of all Forms of Discrimination against Women, GA Res 34/180, UNGAOR, 107 ${ }^{\text {th }}$ plen mtg, Annex, UN Doc A/RES/34/180 (1979)(Herein after CEDAW).
} 
(C) Wilkinson K, 'Is this the Future We Want? An Ecofeminist Comment on the UN Conference on Sustainable Development Outcome Document' in K Rubenstein and KG Young (eds), The Public Law of Gender: From the Local to the Global (Cambridge University Press 2016).

DOI: https://doi.org/10.1017/cbo9781316481493.024

equality. ${ }^{10}$ During the preparatory process, they raised concerns over the inclusion of gender equality in the Outcome Document. In particular, these involved the notion of 'green growth' and the continued affirmation of the dominant growth paradigm. ${ }^{11}$ They were apprehensive that without undertaking a significant paradigm change, gender equality may not be achieved. ${ }^{12}$ The Indigenous Peoples Major Group (IPMG) shared this sentiment and both groups consistently emphasised the importance of Major Group participation in the preparatory process to ensure that sufficient safeguards for women and other marginalised groups were enshrined in the final Outcome Document. ${ }^{13}$ The continued involvement of the IPMG and WMG enabled traditionally excluded voices to be heard in the international sphere during the preparatory stages of the UNCSD.

However, civil society responses to the finalised outcome document were largely negative. Many groups suggested that the future included in the Outcome Document was not one that anyone wanted. ${ }^{14}$ The WMG and IPMG argued that it maintained a damaging, unequal and inequitable social paradigm that incorporated dominant ideological assumptions that 'economic growth' was the way to achieve gender equality and environmental sustainability. ${ }^{15}$ These criticisms were shared by the head of GreenPeace who tweeted 'this is Rio Minus 20 which fails on equity, fails on ecology, Fails [sic] on economy \#rio $+20 \ldots$ text longest suicide note in history. ${ }^{, 16}$ The finalised Outcome Document may not have integrated provisions that challenge

\footnotetext{
${ }^{10}$ Agenda 21 (1992), above n 9, Ch 24.

${ }^{11}$ Intervention by the Women's Major Group on the Zero Drafting Meeting, 26 January 2012 (2012) <http://www.uncsd2012.org/content/documents/700women.pdf> at 26 May 2015.

${ }^{12}$ Ibid.

${ }^{13}$ IPMG and NGO Major Group, Joint Statement by Indigenous Peoples and NGOs Common Cluster (2012) <http://www.uncsd2012.org/content/documents/842Joint\%20Statement\%20Indigenous\%20and\%20NGO.pdf> at 26 May 2015; IPMG, The future Indigenous Peoples Want:Statement by Indigenous Peoples Major Group, (2012) <http://www.uncsd2012.org/content/documents/687indigenous.pdf> at 26 May 2015.

${ }^{14}$ Miriam Anne Frank, 'The Future We Don't Want: Indigenous Peoples at Rio+20' (2012) 36(3) Cultural Survival Quarterly 20, 23 <http://www.culturalsurvival.org/publications/cultural-survival-quarterly/future-we-dontwant-indigenous-peoples-rio20> at 26 May 2015; WMG, Rio+20: From the Future We Want to the Future We Need: Women's Major Group Final Statement on the Outcomes of Rio+20 (2012) Women's Environment \& Development Organization 1 <http://www.wedo.org/wp-content/uploads/Womens-Major-GroupRIO+20_FINAL-STATEMENT_24-June-2012.pdf> at 26 May 2015.

15 See, WMG, 'From the Future We Want to The Future We Need', above n 14, 2-3; Tebtebba, Indigenous Peoples Release Rio+20 Declaration (2012) Tebtebba: Indigenous Peoples' International Centre for Policy Research and Education <http://tebtebba.org/index.php/content/220-indigenous-peoples-release-rio-20declaration> at 26 May 2015.

${ }^{16}$ Kumi Naidoo, Twitter post @ kuminaidoo, 19 June 2012 at 5:06pm, Twitter

<https://twitter.com/kuminaidoo/status/215113320632561664> at 26 May 2015.
} 
(C) Wilkinson K, 'Is this the Future We Want? An Ecofeminist Comment on the UN Conference on Sustainable Development Outcome Document' in K Rubenstein and KG Young (eds), The Public Law of Gender: From the Local to the Global (Cambridge University Press 2016).

DOI: https://doi.org/10.1017/cbo9781316481493.024

paradigms that many perceive as maintaining the unequal and destructive society in which the international community finds itself and sustainable development was meant to address.

\section{Sustainable Development, the green economy and the 'Dominant Social Paradigm'}

Ecofeminists share with other critical theorists a critique of dominant social paradigms upon which Western culture and the international community is built. These paradigms are made up of institutions, habits, and values that together, provide social lenses through which groups and individuals interpret the social world. ${ }^{17}$ They ensure societal harmony by creating shared deprivations and gains, and conditioning individual goals and expectations. ${ }^{18}$

In Western society, some argue that the dominant social paradigm includes a belief that the primary goal for governments, after national defence, is to create conditions which increase commodity production and satisfy the materialist needs of citizens. ${ }^{19}$ Inherent in this goal is belief that society's ills can be solved by technology and that 'economic growth' is a measure of progress. ${ }^{20}$ These paradigms shape the ways in which the international community responds to global concerns such as environmental degradation, poverty and economic development.

Such beliefs inform the concept of sustainable development and the green economy.

Sustainable development is defined as 'development that meets the needs of the present without compromising the ability of future generations to meet their own needs. ${ }^{21}$ It aims to integrate three goals of economic development, environmental protection and social equity in a mutually supportive manner. ${ }^{22}$ The concept of a green economy has been put forward as a way to achieve sustainable development and poverty eradication, whilst protecting the environment and contributing to social development. ${ }^{23}$ The green economy has come into prominence during the recent economic recession. However, some criticise the concept because it

\footnotetext{
${ }^{17}$ Lester W Milbrath, 'Culture and the Environment in the United States' (1985) 9(2) Environmental Management 161, 163; Dennis C Pirages and Paul R Ehrlich, Ark II: Social Response to Environmental Imperatives (WH Freeman \& Co, 1974) 43.

${ }^{18}$ Milbrath, above n 17, 163.

${ }^{19}$ Bill Devall, 'The Deep Ecology Movement' (1980) 20(2) Natural Resources Journal 299, 300; see also Pirages and Ehrlich, above n 17, 69.

${ }^{20}$ Devall, above n 19, 300 .

${ }^{21}$ World Commission on Environment Development, Our Common Future (Oxford University Press, 1987$) 43$.

22 John Drexhage and Deborah Murphy, 'Sustainable Development: From Brundtland to Rio 2012' (Background Paper prepared for the High Level Panel on Global Sustainability, United Nations Headquarters, New York, 19 September 2010), 2, 8 <http://www.un.org/wcm/webdav/site/climatechange/shared/gsp/docs/GSP1-

6_Background\%20on\%20Sustainable\%20Devt.pdf $>$ at 26 May 2015.

${ }^{23}$ The Future We Want, GA Res 66/288, UN GAOR, 66 ${ }^{\text {th }}$ Sess, Agenda Item 19, [56], UN Doc A/RES/66/288 (2012)..
} 
(C) Wilkinson K, 'Is this the Future We Want? An Ecofeminist Comment on the UN Conference on Sustainable Development Outcome Document' in K Rubenstein and KG Young (eds), The Public Law of Gender: From the Local to the Global (Cambridge University Press 2016).

DOI: https://doi.org/10.1017/cbo9781316481493.024

incorporates the dominant social paradigm by maintaining a belief that 'growth' is fundamental for economic well-being.

The United Nations Environment Programme (UNEP) advocates increasing technological transfer of renewable energies as part of its green economy initiative. ${ }^{24}$ Referring to green economy success stories, UNEP cites public/private cooperation, and technology transfers to increase the new installations of wind turbines as part of a move to 'low-carbon growth' strategies. ${ }^{25}$ Inherent in this, is the assumption that such strategies support social and economic development at the national level by investing in large scale renewable energy projects. ${ }^{26}$ Not only does the green economy commoditise the environment, it also perpetuates the belief that technology will solve society's problems. ${ }^{27}$ Therefore, the green economy may incorporate assumptions inherent in the dominant social paradigm which may inform the way in which it responds to issues such as gender equality.

\section{Ecofeminism: a social movement and theoretical framework}

Both sustainable development and the green economy aim to achieve gender equality by empowering women to participate actively in all areas of public life. ${ }^{28}$ However, ecofeminists have criticised the assumptions inherent in this justification because they aim to assimilate

\footnotetext{
${ }^{24}$ UNEP, "Global Green New Deal" - Environmentally-Focused Investment Historic Opportunity for 21 st Century Prosperity and Job Generation (2008) United Nations Environment Programme: News Centre, 22 October 2008 $<$ http://www.unep.org/documents.multilingual/default.asp?DocumentID=548\&ArticleID=5957\&l=en> at 26 May 2015.

${ }^{25}$ Pavan Sukhdev, Steven Stone and Nick Nuttall, 'Green Economy: Developing Countries Success Stories' (UNEP 2010) 8-9 <http://www.unep.org/pdf/GreenEconomy_SuccessStories.pdf > .

${ }^{26}$ See UNDESA, 'A Global Green New Deal for Climate, Energy, and Development' (2009) 14

$<$ http://sustainabledevelopment.un.org/content/documents/cc_global_green_new_deal.pdf> at 26 May 2015; UNEP, 'Global Green New Deal: Policy Brief' (2009) 7-8

<http://www.unep.org/pdf/A_Global_Green_New_Deal_Policy_Brief.pdf> at 26 May 2015.

${ }^{27}$ José Antonio Ocampo, 'Summary of Background Papers' in The Transition to a Green Economy: Benefits, Challenges and Risks from a Sustainable Development Perspective: Report by a Panel of Experts to Second Preparatory Committee Meeting for United Nations Conference on Sustainable Development (United Nations Department of Economic and Social Affairs (UNDESA), UN Division for Sustainable Development; United Nations Environment Programme (UNEP), UN Conference on Trade and Development (UNCTAD), 2011) 7 <http://www.uncsd2012.org/rio20//content/documents/Transition\%20to\%20a\%20Green\%20Economy_summary. pdf $>$ at 26 May 2015. The authors note that in order to achieve a green economy requires 'no less than a technological revolution.' They further state that technology transfer and development should be a core strategy in achieving a green economy.

${ }^{28}$ See the contributions in Blerta Cela, Irene Dankelman and Jeffrey Stern (eds), Powerful Synergies: Gender Equality, Economic Development and Environmental Sustainable Development (United Nations Development Programme 2013).
} 
(C) Wilkinson K, 'Is this the Future We Want? An Ecofeminist Comment on the UN Conference on Sustainable Development Outcome Document' in K Rubenstein and KG Young (eds), The Public Law of Gender: From the Local to the Global (Cambridge University Press 2016).

DOI: https://doi.org/10.1017/cbo9781316481493.024

women and other 'marginalised Others' within the dominant social paradigm without examining how that paradigm maintains the subordination of these social groups. ${ }^{29}$

Like many feminist perspectives, there is more than one type of ecofeminism. ${ }^{30}$ It is not a homogenous theory and integrates different discourses. ${ }^{31}$ Ecofeminists start from the position that the way we treat each other and nature is indivisible. ${ }^{32}$ They use this premise to approach problems such as environmental degradation and social inequality. ${ }^{33}$ Therefore, an ecofeminist critique can reveal important connections between the exploitation of women and the exploitation of the environment within discourses such as sustainable development. ${ }^{34}$

In this chapter, I use ecofeminism to analyse the language of the Outcome Document as a gateway to highlight the assumptions inherent in the concepts, objectives and discourses that are included in the text, particularly in the context of gender equality, sustainable development and the green economy. This is because ecofeminism features environmental exploitation in its list of 'interwoven forms of oppression such as sexism, heterosexism, racism and ethnocentrism. ${ }^{35}$ This form of critique is a useful lens through which to examine the extent to which the Outcome Document moves the concepts of gender equality in sustainable

\footnotetext{
${ }^{29}$ Val Plumwood, Environmental Culture: The ecological Crisis of Reason (Routledge, 2002) 71-80; Maria Mies and Vandana Shiva, Ecofeminism (Kali for Women: Zed, 1993) 11-16; Vandana Shiva, Staying Alive: Women, Ecology and Development (Zed, 1988) 3-4.

${ }^{30}$ For more discussion concerning the different strands of ecofeminism and its contribution to feminism, see Mary Mellor, Feminism \& Ecology (Polity Press, 1997), 44-70; Catriona Sandilands, The Good-Natured Feminist: Ecofeminism and the Quest for Democracy (University of Minnesota Press, 1999) 20-27. The women/Nature connection within ecofeminism has been criticised by ecofeminists and feminists alike for the assumption that women's nature is inherently nurturing. However, these issues have been addressed by ecofeminists themselves, see Greta Gaard, 'Ecofeminism Revisited: Rejecting Essentialism and Re-Placing Species in a Material Feminist Environmentalism' (2011) 23(2) Feminist Formations 26; Val Plumwood, Feminism and the Mastery of Nature (Routledge, 1993) 9; Niamh Moore, 'The Rise and Rise of Ecofeminism as a Development Fable: A Response to Melissa Leach's 'Earth Mothers and Other Ecofeminist Fables: How a Strategic Notion Rose and Fell' (2008) 39(3) Development and Change 461; Charis Thompson, 'Back to Nature? Resurrecting Ecofeminism after Poststructuralist and Third-Wave Feminisms' (2006) 97(3) Isis 505.

${ }^{31}$ See e.g. Bina Agarwal, 'The Gender and Environment Debate: Lessons from India' (1992) 18(1) Feminist Studies 119, 120; Grace Y Kao, 'The Universal Versus the Particular in Ecofeminist Ethics ' (2010) 38(4) Journal of Religious Ethics 616, 617; Annie Rochette, 'Stop the Rape of the World: An ecofeminist Critique of Sustainable Development' (2002) 51 University of New Brunswick Law Journal 145, 150; see also Cecile Jackson, 'Women/Nature or Gender/History? A Critique of Ecofeminist 'Development' (1993) 20(3) The Journal of Peasant Studies 389.

${ }^{32}$ Greta Gaard, 'Women, Water, Energy: An Ecofeminist Approach' (2001) 14 Organization Environment 157, 158.

${ }^{33}$ Ibid.

${ }^{34}$ Agarwal, above n 31, 119. See also Niamh Moore, 'Eco/Feminism and Rewriting the End of Feminism: From the Chipko Movement to Clayoquot Sound' (2011) 12(1) Feminist Theory 3; Rosi Braidotti et al, Women, the Environment and Sustainable Development: Towards a Theoretical Synthesis (Zed Press, 1994); Shiva, Staying Alive, above $\mathrm{n} 29$.

${ }^{35}$ Stephanie Lahar, 'Ecofeminist Theory and Grassroots Politics' (1991) 6(1) Hypatia 28, 29.
} 
(C) Wilkinson K, 'Is this the Future We Want? An Ecofeminist Comment on the UN Conference on Sustainable Development Outcome Document' in K Rubenstein and KG Young (eds), The Public Law of Gender: From the Local to the Global (Cambridge University Press 2016).

DOI: https://doi.org/10.1017/cbo9781316481493.024

development and the green economy beyond the dominant social paradigm. It offers the most complete theoretical framework for this chapter because it can highlight the multiple intersections of dominant assumptions that form the basis of arguments for assimilating women and other marginalised groups into sustainable development and the green economy.

Ecofeminists argue that exploitative and gendered conceptual frameworks underpin the dominant and rational discourses in Western society. ${ }^{36}$ These frameworks are formed by a set of values, attitudes, beliefs and assumptions that shape and mirror how an entity views itself and the world around it. ${ }^{37}$ They can function as a 'socially constructed lens through which one perceives reality. ${ }^{38}$ Therefore, a number of different factors such as class, religion, nationality, gender, and race/ethnicity can alter the social lens. In particular, ecofeminists critique how these frameworks, and their inherent logical structures continue to exclude, devalue and subordinate human others, and nonhuman nature. ${ }^{39}$ This analysis of the underlying concepts and logical structures of rational discourses in Western thinking is useful when analysing the assumptions behind the arguments for assimilating women and other marginalised groups into the green economy.

Some ecofeminists have examined the structures and assumptions inherent in the concept that mean the environment continues to be damaged and that marginalise women, the poor and 'Others. ${ }^{40}$ Val Plumwood suggests that the oppression of nonhuman nature stems from a 'system of interlocking, oppressive structures based on a series of hierarchical dualisms that lie at the heart of Western culture. ${ }^{41}$ She argues that Western culture is constructed through a series of logical structures that deny dependency on nature and that which is associated with nature, such as women, reproduction and the body. ${ }^{42}$

\footnotetext{
${ }^{36}$ See, eg, Plumwood, Environmental Culture above n 29, 19; Karen J Warren, Ecofeminist Philosophy: A Western Perspective on What It Is and Why It Matters (Rowman \& Littlefield, 2000), 27-38; Karen J Warren, 'Taking Empirical Data Seriously: an Ecofeminist Philosophical Perspective' in Karen J Warren and Nisvan Erkal (eds), Ecofeminism: Women, Culture, Nature (Indiana University Press, 1997) 3, 13-14; Plumwood, Feminism and the Mastery of Nature, above n 30, 36.

${ }^{37}$ Warren, Ecofeminist Philosophy, above n 36, 46.

${ }^{38}$ Ibid.

${ }^{39}$ Plumwood, Feminism and the Mastery of Nature, above n 30, 41-42.

${ }^{40}$ Annie Rochette, 'Transcending the Conquest of Nature and Women: A Feminist Perspective on International Environmental Law' in Doris Buss and Ambreena Manji (eds), International Law: Modern Feminist Approaches (Hart, 2005) 203, 204.

${ }^{41}$ Gaard, 'Women, Water, Energy', above n 32, 158.

42 Ibid, 159.
} 
(C) Wilkinson K, 'Is this the Future We Want? An Ecofeminist Comment on the UN Conference on Sustainable Development Outcome Document' in K Rubenstein and KG Young (eds), The Public Law of Gender: From the Local to the Global (Cambridge University Press 2016).

DOI: https://doi.org/10.1017/cbo9781316481493.024

These structures are formed by dualisms that result from 'a certain kind of denied dependency on a subordinated other. ${ }^{43}$ Dualisms are contrasting pairs in which the privileged Western 'self' is defined by its property of characteristics such as culture, reason, mind, and rationality. These are by definition opposite to nature, and those characteristics associated with nature, such as nature, female, body and reproduction. ${ }^{44}$ This logical structure privileges those entities that contain the qualities of the valued side of the dualism while serving to diminish those who are associated with the qualities of the devalued side. From these hierarchical dualisms, the logical structure of dualism maintains a separation between 'self' and other through a number of linking postulates that maintain and reinforce the distinction and separation of the Other from the self. ${ }^{45}$ These critiques are particularly useful when examining the integration of gender equality in the discourse of sustainable development and the 'green economy.'

Drawing on these critiques, some ecofeminists examine how Western rationalist ideology has informed social systems, such as the market economy and its effect on women and nonhuman nature. ${ }^{46}$ They argue that the current economic system is gendered and prioritises a model that is disembodied, decontextualized and therefore is unable to represent the 'reality of most women's lives. ${ }^{47}$ They state that Western rationalist ideology separates activities defined as 'economic' from those that are non-economic and this separation occurs along gendered lines. They suggest this undervalues the (non) economic contributions by women by prioritising 'what men value and what men do. ${ }^{48}$ These critiques are particularly relevant when examining the assumptions inherent in the green economy and the way in which women and other marginalised groups are assimilated into it.

Ecofeminism can also offer a critique of the concept of 'gender equality' as promoted through sustainable development. Many assume that incorporating gender equality into sustainable development means that women (and marginalised 'others') can contribute to the global

\footnotetext{
${ }^{43}$ Plumwood, Feminism and the Mastery of Nature, above n 30, 41.

${ }^{44}$ Ibid; Gaard, 'Women, Water, Energy', above n 32.

${ }^{45}$ See Plumwood, Feminism and the Mastery of Nature, above n 30, 47-55.

${ }^{46}$ See e.g. Mary Mellor, 'Ecofeminist Political Economy: Integrating Feminist Economics and Ecological Economics' (2005) 11(3) Feminist Economics 120.

${ }^{47}$ Mary Mellor, 'Women, Nature and the Social Construction of 'Economic Man” (1997) 20(2) Ecological Economics 129, 130.

${ }^{48}$ Ibid; Marilyn Waring, 'Counting for Something! Recognising Women's Contribution to the Global Economy Through Alternative Accounting Systems' (2003) 11(1) Gender and Development 35, 36; Marilyn Waring, 'The Invisibility of Women's Work: The Economics of Local and Global "Bullshit"' (1997) 17(2) Canadian Woman Studies/Les Cahiers de la Femme 31, 31.
} 
(C) Wilkinson K, 'Is this the Future We Want? An Ecofeminist Comment on the UN Conference on Sustainable Development Outcome Document' in K Rubenstein and KG Young (eds), The Public Law of Gender: From the Local to the Global (Cambridge University Press 2016).

DOI: https://doi.org/10.1017/cbo9781316481493.024

response against environmental degradation and the failure to control and regulate environmental pollutants. ${ }^{49}$ They suggest that supporting women's access to education and giving them equal opportunities alongside men to become scientists, lawyers, regulators, and legislators will improve the environment and ensure a higher quality of life for both sexes. ${ }^{50}$ This approach has been labelled 'liberal ecofeminism' 51 and has been criticised because it does not question the structures of the dominant social model and its underlying ideological and conceptual apparatus. ${ }^{52}$ In the context of sustainable development, liberal ecofeminist responses may not acknowledge the masculine bias in the dominant model of the human as opposite to nature in human culture. ${ }^{53}$ Therefore, it may endorse a model which incorporates assumptions of class, race and the supremacy of the human species. ${ }^{54}$

Arguments for inclusive participation by marginalised groups in current institutions and governance structures have significant merit. However, without engaging with wider criticisms of the dominant model and the ways in which it maintains the subordination of women and nonhuman nature in dominant social institutions, relegates these projects to ones of 'uncritical equality ${ }^{55}$ where women overcome the stigma of their sex and work with men in projects of environmental conservation. ${ }^{56}$ Engaging in this critique may help understand the extent to which the Outcome Document undertakes such a project in its vision of sustainable development and the 'green economy.'

\section{Gender Equality and Sustainable Development}

Ecofeminists are concerned that sustainable development continues to integrate androcentric assumptions based in logical structures that privilege the Western, rationalist model that separates humanity from nonhuman nature. ${ }^{57}$ They maintain that the model contained in the concept of sustainable development is founded on the assumption of humanity's domination of

\footnotetext{
${ }^{49}$ Carolyn Merchant, 'Ecofeminism and Feminist Theory' in Irene Diamond and Gloria Feman Orenstein (eds), Reweaving the World: The Emergence of Ecofeminism (Sierra Club Books, 1990) 100, 100-101.

${ }^{50}$ Ibid, 101.

${ }^{51}$ Carolyn Merchant, Earthcare: Women and the Environment (Routledge, 1996), 8-10.

52 Plumwood, Feminism and the Mastery of Nature, above n 30, 29.

53 Ibid.

54 Ibid

${ }^{55}$ Ibid.

${ }^{56}$ Merchant, 'Ecofeminism and Feminist Theory', above n 49, 101.

${ }^{57}$ Betty Wells and Danielle Wirth, 'Remediating Development through an Ecofeminist Lens' in Karen J Warren and Nisvan Erkal (eds), Ecofeminism: Women, Culture, Nature (Indiana University Press, 1997), 301.
} 
(C) Wilkinson K, 'Is this the Future We Want? An Ecofeminist Comment on the UN Conference on Sustainable Development Outcome Document' in K Rubenstein and KG Young (eds), The Public Law of Gender: From the Local to the Global (Cambridge University Press 2016).

DOI: https://doi.org/10.1017/cbo9781316481493.024

nature and legitimates the 'sustainable' exploitation of the environment. ${ }^{58}$ This assumption may have a negative impact on women's material security because they often have lower economic advantage and political power. ${ }^{59}$ In addition, sustainable development places a 'disproportionate responsibility for safeguarding the planet' ${ }^{60}$ onto women under the assumption that they would want to be integrated into a 'patriarchal Western model of development. ${ }^{61}$ Bearing this in mind, the following discussion will examine the preparations for the UNCSD and the extent to which the WMG and UN-Women were able to contribute to this process.

\section{Women's participation in the preparatory process}

As noted above, Governments and stakeholders, including the Major Groups, contributed to the Zero Draft of the Outcome Document that would be the text that high-level Ministers and Heads of States would negotiate at the UNCSD. From the start, women were involved in all stages of the preparatory process. This inclusive participation and interaction between Governments and stakeholders was seen as 'precedent setting' 62 by some State delegates and suggests that the UNCSD actively encouraged the participation of the Major Groups.

This inclusive participation meant that the WMG were able to raise concerns over gender equality and gender sensitivity at different stages of the preparation process. During the Regional Preparatory Meetings, the WMG called for women to participate in all issues addressed at the UNCSD and for States to consider gender in sustainable development and the 'green economy. ${ }^{63}$ These concerns were reiterated by WMG Representatives at most other regional meetings. ${ }^{64}$ The participation and interventions by the WMG suggest that the UNCSD

\footnotetext{
${ }^{58}$ See e.g. Carolyn Merchant, The Death of Nature: Women, Ecology and the Scientific Revolution (Harper, 1980); Agarwal, above n 31.

${ }^{59}$ Agarwal, above n 31, 122-123; Shiva, Staying Alive, above n 29, 3.

${ }^{60}$ Charlotte Bretherton, 'Movements, Networks, Hierarchies: A Gender Perspective on Global Environmental Governance' (2003) 3(2) Global Environmental Politics 103, 103.

${ }^{61}$ Braidotti et al, above n 34, 80.

${ }^{62}$ Leila Mead, Eugenia Recio and Anna Schulz, 'Summary of the UNCSD (Rio+20) Regional Preparatory Meeting for Latin America and the Caribbean: 7-9 September 2011' (2011) 27(7) Earth Negotiations Bulletin 1, 1 $<$ http://www.iisd.ca/uncsd/preplac/> at 26 May 2015; Leila Mead, Olivia Pasini and Simon Wolf, 'Summary of the UNCSD (Rio+20) Arab Regional Preparatory Meeting: 16-17 October 2011' (2011) 27(8) Earth Negotiations Bulletin 1, $1<\mathrm{http}: / /$ www.iisd.ca/uncsd/prepa/> at 26 May 2015.

${ }^{63}$ WMG, Women's Major Group Intervention Plenary Session, Latin America and Caribbean Regional Meeting Preparatory to the United Nations Conference on Sustainable Development, 2 <http://www.cepal.org/rio20/noticias/paginas/9/43799/1.7_Sept.Grupo_Mujeres.ENG.pdf> at 26 May 2015; Mead, Pasini and Wolf, 'Summary of the Arab Regional Preparatory meeting', above n 62, 8.

${ }^{64}$ Mead, Pasini and Wolf, 'Summary of the Arab Regional Preparatory meeting', above n 62, 1; Peter Doran, Nathalie Risse and Andrey Vavilov, 'Summary of the UNCSD (Rio+20) Regional Preparatory Meeting for
} 
(C) Wilkinson K, 'Is this the Future We Want? An Ecofeminist Comment on the UN Conference on Sustainable Development Outcome Document' in K Rubenstein and KG Young (eds), The Public Law of Gender: From the Local to the Global (Cambridge University Press 2016).

DOI: https://doi.org/10.1017/cbo9781316481493.024

preparatory process has enabled the participation and involvement of traditionally marginalised groups, and indicate that the criticisms of earlier conferences have been acknowledged.

The Major Groups and wider civil society were able to contribute to the first compilation of the 'Zero Draft' ${ }^{65}$ They could also participate during the informal and intercessional consultations. ${ }^{66}$ During these consultations, they were able to reiterate their concerns over the green economy and the continued affirmation of the privatisation and commodification of nature, social inequality and the use of structural adjustment policies. ${ }^{67}$ They argued that the integration of neo-liberal development subordinated women and nonhuman nature at the expense of sustainable and equal living. Therefore, they called for the Outcome Document to recognise the need for a major paradigm shift. ${ }^{68}$

These examples indicate a continued integration and affirmation of inclusive participation by all Major Groups in the development of future sustainable development goals and policy. This inclusive participation often surprised the Major State delegates. ${ }^{69}$ Therefore, the level of participation by women and other Major Groups suggests that the preparatory process for the UNCSD involved inclusive and open participation by women. This suggests that the Member States have continued to support gender mainstreaming and equality in all areas of international sustainable development policy.

\section{Gender Equality incorporated in the Outcome Document}

The Outcome Document makes numerous references to gender equality in the context of the green economy ${ }^{70}$ and sustainable development. ${ }^{71}$ In the following discussion, I will examine

\footnotetext{
Europe: 1-2 December 2011' (2011) 27(11) Earth Negotiations Bulletin 1, 5, 8 <http://www.iisd.ca/uncsd/prepe/> at 26 May 2015; Kate Louw, Dorothy Wanja Nyingi and Simon Wolf, 'Summary of the UNCSD (Rio+20) Regional Preparatory Meeting for Africa: 20-25 October 2011' (2011) 27(10) Earth Negotiations Bulletin 1, 1 <http://www.iisd.ca/uncsd/prepaf/> at 26 May 2015.

${ }^{65}$ See e.g. Lakshmi Puri, Statement at the Initial Consultations on the Zero Draft of the Rio+20 Outcome Document (Statement delivered at the UN Conference on Sustainable Development, New York, 25 January 2012) <http://www.uncsd2012.org/content/documents/692unwomen.pdf> at 26 May 2015.

66 Ibid, 1-2.

${ }^{67}$, Women's Major Group above n 11, 1.

${ }^{68}$ Ibid, 1.

${ }^{69}$ Mead, Pasini and Wolf, 'Summary of the Arab Regional Preparatory meeting', above n 62, 1. 'Major Groups actively and eloquently engaged in this meeting in an unprecedented manner for UN regional processes, according to some delegates, who were quite surprised at the level of participation.'

${ }^{70}$ See, eg, The Future We Want, above n 23, [58(k)]. The Document states that the green economy should 'enhance the welfare of women'.

${ }^{71}$ Ibid, [31]. The Document recognises that 'gender equality and women's empowerment are important for sustainable development and our common future.'
} 
(C) Wilkinson K, 'Is this the Future We Want? An Ecofeminist Comment on the UN Conference on Sustainable Development Outcome Document' in K Rubenstein and KG Young (eds), The Public Law of Gender: From the Local to the Global (Cambridge University Press 2016).

DOI: https://doi.org/10.1017/cbo9781316481493.024

some of these references and the extent to which they engage with underlying barriers to equal participation.

Many of the provisions in the Outcome Document refer to the inclusion of women in the institutional aspects of sustainable development, such as decision-making, policy development and the implementation of goals. ${ }^{72}$ The text consistently affirms that women have 'a vital role to play in achieving sustainable development. ${ }^{, 73}$ It supports the 'leadership role of women' and resolves to 'promote gender equality and women's empowerment. ${ }^{74}$ Examples of women's empowerment contained in the Document include the 'full and effective participation in sustainable development policies, programmes and decision making at all levels. ${ }^{, 75}$ This approach continues the commitment to gender equality through integration and inclusion as articulated in earlier international declarations, such as the Beijing Declaration (1995). ${ }^{76}$

The Outcome Document recognises the different ways in which society experiences sustainable development and aims to incorporate gender equality as a tool to address this. It acknowledges that women are disproportionately affected by environmental degradation and that a significant portion of the world's poor are reliant on subsistence agriculture and the local environment for survival. ${ }^{77}$ It affirms rural women as 'critical agents for enhancing agricultural ... development and food security ${ }^{78}$ and recommends that rural communities' needs, such as access to markets and affordable technologies, should be addressed. ${ }^{79}$ These examples suggest that the Outcome Document has included gender equality and that the Document has taken into account different experiences of women and other marginalised groups

The Outcome Document recognises that reducing inequality and social exclusion are important to achieve sustainable development. ${ }^{80}$ In this context, the Document promotes universal access to social services as they can address and reduce inequality. ${ }^{81}$ It commits to supporting the rights of women to have 'control over and decide freely and responsibly on matters relating to

\footnotetext{
${ }^{72}$ Ibid, [11], [42]-[55], [193].

${ }^{73}$ Ibid, [45].

${ }^{74}$ Ibid, [45].

${ }^{75}$ Ibid, [35], [45], [236]-[237].

${ }^{76}$ Beijing Declaration, above n 9, [16], [36].

77 The Future We Want, above n 23, [108]-[109].

${ }^{78}$ Ibid, [109].

${ }^{79}$ Ibid, [109], see also [118].

${ }^{80}$ Ibid, [107], see also [105].

${ }^{81}$ Ibid, [107].
} 
(C) Wilkinson K, 'Is this the Future We Want? An Ecofeminist Comment on the UN Conference on Sustainable Development Outcome Document' in K Rubenstein and KG Young (eds), The Public Law of Gender: From the Local to the Global (Cambridge University Press 2016).

DOI: https://doi.org/10.1017/cbo9781316481493.024

their sexuality. ${ }^{, 82}$ It calls for the 'full and effective implementation' of various international commitments concerning reproductive health and for universal access to reproductive health to be integrated into national programmes. ${ }^{83}$ These examples suggest that the Document has acknowledged some of the barriers to gender equality in the context of attaining sustainable development.

The Outcome Document recognises that barriers to women's empowerment occur through limited access to decision-making and participation in policy development. It notes the disproportionate impact on women by ecosystem degradation. It affirms that reproductive health and universal access to health care are integral for the achievement of sustainable development. These paragraphs have been applauded as 'small steps forward' by the WMG. ${ }^{84}$

However, an ecofeminist analysis of these examples suggests that the Outcome Document assimilates women (and other marginalised groups) into the dominant project of sustainable development, rather than engaging with the underlying causes of gender inequality. The examples discussed above demonstrate an approach that addresses inequalities through existing governance structures and by including provisions relating to women. ${ }^{85}$ This is seen in the Outcome Document's commitment to including women in established governance structures and promoting their participation in policy development and decision-making for sustainable development.

In this liberal approach, the rationalist model conceptualises the human as 'exclusive of nature' and by extension includes assumptions of 'gender supremacy... class, race and species supremacy. ${ }^{86}$ Therefore, the focus on technological 'improvements' and in educating women and other 'Others' in the use of such technology for agricultural productivity may be read as an example of an androcentric vision of sustainable development which considers nature and women as 'other' and in need of assimilating into a male-oriented and defined concept of

\footnotetext{
${ }^{82}$ Ibid, [146].

${ }^{83}$ Ibid, [147]. The Document makes reference to the Beijing Declaration and Platform for Action (1995), and the Programme of Action of the International Conference on Population and Development: Report of the International Conference on Population and Development, UN Doc A/CONF.171/13/Rev.1 (1994).

${ }^{84}$ WECF, Report: Activities, Commitments and Results at Rio+20 Acheived by Members of the Women's Major Group and WECF in the Run Up to Rio and from 13-22 of June (24 July 2012) WECF 10 <http://www.wecf.eu/download/2012/july/ReportGeneralRio20WMG.pdf> at 26 May 2015.

${ }^{85}$ Merchant, Earthcare, above n 51, 5; Annie Rochette, Rape of the World: An Ecofeminist Critique of International Environmental Law (Master of Laws (LLM) Thesis, University of British Columbia, 1998) 18 <https://circle.ubc.ca/handle/2429/8236> at 26 May 2015.

${ }^{86}$ Plumwood, Feminism and the Mastery of Nature, above n 30, 28.
} 
(C) Wilkinson K, 'Is this the Future We Want? An Ecofeminist Comment on the UN Conference on Sustainable Development Outcome Document' in K Rubenstein and KG Young (eds), The Public Law of Gender: From the Local to the Global (Cambridge University Press 2016).

DOI: https://doi.org/10.1017/cbo9781316481493.024

development. ${ }^{87}$ This, according to ecofeminists and some participants at the UNCSD, means that the concept of sustainable development does not challenge the assumptions of the dominant social paradigm focusing on economic growth and productivity. ${ }^{88}$

\section{The green economy and Gender Equality}

Resolution 64/236 decided that the Conference and preparatory process should 'ensure the balanced integration' 89 of the three pillars of sustainable development: economic development, environmental protection and social development because they are 'interdependent and mutually reinforcing components of sustainable development. ${ }^{90}$ However, a significant portion of the preparatory process focussed on the green economy and how it may support or detract from sustainable development goals. In the following discussion I will examine the integration of gender quality in the green economy and the extent to which it moves beyond the dominant social paradigm, if at all.

\section{The green economy in the preparatory process}

From the start of the UNCSD preparations, it was clear there was no consensus over the concept of a 'green economy. ${ }^{91}$ During the first preparatory meeting, it was agreed that the concept should be 'understood in the context of sustainable development and consistent with the Rio principles. ${ }^{92}$ However, a significant proportion of delegates and wider civil society were concerned that the concept would detract from the interrelated nature of sustainable development and risked monetising the natural environment through the concept of 'ecosystem services. ${ }^{93}$ These also relate to the predominately economic, techno-centric approaches integrated within the green economy and the extent to which the concept acknowledges nonmonetary contributions by women.

\footnotetext{
${ }^{87}$ Shiva, Staying Alive, above n 29, 5-6, 41; see also Mies and Shiva, above n 29, 22-35.

${ }^{88}$ Rochette, 'Stop the Rape of the World', above n 31, 155-157; see also Vandana Shiva, 'Development as a New Project of Western Patriarchy' in Irene Diamond and Gloria Feman Orenstein (eds), Reweaving the World: The Emergence of Ecofeminism (Sierra Club Books, 1990) 189.

${ }^{89}$ Implementation of Agenda 21, above n 3, [20(d)].

${ }^{90}$ Ibid..

${ }^{91}$ Report of the Preparatory Committee for the United Nations Conference on Sustainable Development, Comm for the UN Conference on Sustainable Development, 1st Sess, [53], UN Doc A/CONF/.216/PC/5 (2010).

92 Ibid, [53]. The Rio principles refer to the principles contained in the Rio Declaration (1992) .

${ }^{93}$ Ibid, [56], [59]; Chris Spence and Andrey Vavilov, 'Summary of the First PrepCom for the UN Conference on Sustainable Development: 17-19 May 2010' (2010) 27(1) Earth Negotiations Bulletin 1, 4 <http://www.iisd.ca/download/pdf/enb2701e.pdf> at 26 May 2015.
} 
(C) Wilkinson K, 'Is this the Future We Want? An Ecofeminist Comment on the UN Conference on Sustainable Development Outcome Document' in K Rubenstein and KG Young (eds), The Public Law of Gender: From the Local to the Global (Cambridge University Press 2016).

DOI: https://doi.org/10.1017/cbo9781316481493.024

The IPMG and WMG maintained that the green economy focused primarily on technocentic remedies and projects in order to achieve 'green growth.' In particular, IPMG criticised the label of 'sustainable' or 'green' energy for hydroelectric dams and nuclear power projects because these projects have a significant impact on livelihoods and culture of indigenous communities. ${ }^{94}$ Both the WMG and the IPMG queried the integration of biofuels as a source of 'green' energy because they lead to mono-cropping and land-grabs which have an adverse impact on the local environment and marginalises women and indigenous peoples. ${ }^{95}$ They argued that these projects restricted local community's livelihoods and destroyed their culture and lands. ${ }^{96}$ Therefore framing large-scale development projects such as hydroelectric power and dam-building as strategies for green growth through renewable energy production, continues to reaffirm the Western dominant social paradigm where productive, economic growth is seen as the primary measure of development. This approach discounts and devalues other forms of production not reliant on large-scale energy production. These examples reflect ecofeminist critiques of Western development that appropriates and alters (or destroys) the environment and thereby its resource base for sustenance or survival. ${ }^{97}$

The WMG and IPMG questioned the incorporation of 'sustained economic growth' in the 'green economy.' 98 They argued that the incorporation of 'growth' in the concept and its affirmation 'structural adjustment policies" ${ }^{99}$ did not recognise the impact of such approaches on women and marginalised communities. They stated that such policies affirmed the 'privatisation, commodification of nature, social inequality and hunger.' ${ }^{100}$ These concerns reflect ecofeminist critiques of development strategies that integrate mainstream economics.

\footnotetext{
94 'Additional Statement of Indigenous Peoples on the Green Economy' (Statement delivered at the First Preparatory Committee Meeting, UN Conference on Sustainable Development, New York, 18 May 2010) <http://www.uncsd2012.org/content/documents/Indigenous_peoples2.pdf>; Women's Major Group, above n 11, 1 .

95 'Additional Statement of Indigenous Peoples' above n 94, 1.

96 Ibid.

${ }^{97}$ Shiva, Staying Alive, above n 29, 3.

98 'Statement of Indigenous Peoples' (Statement delivered at the First Preparatory Meeting of the UN Conference on Sustainable Development, Sess 2: A Green Economy in the Context of Sustainable Development and Poverty Eradication, New York, 18 May 2010) <http://www.uncsd2012.org/content/documents/Indigenous_peoples.pdf> at 26 May 2015.

${ }^{99}$ Women's Major Group, above n 11, 1; Marcos Terena, 'Indigenous Peoples Statement' (Statement delivered at the First Intersessional Meeting of the UN Conference on Sustainable Development, New York, 11 January 2011 <http://www.uncsd2012.org/content/documents/IndigenousPeople-1st-Intersessional-11Jan.pdf> at 16 May 2015. ${ }^{100}$ Women's Major Group, above n 11, 1; Marcos Terena, 'Indigenous Peoples Statement', above n 99.
} 
(C) Wilkinson K, 'Is this the Future We Want? An Ecofeminist Comment on the UN Conference on Sustainable Development Outcome Document' in K Rubenstein and KG Young (eds), The Public Law of Gender: From the Local to the Global (Cambridge University Press 2016).

DOI: https://doi.org/10.1017/cbo9781316481493.024

Ecofeminists argue that these approaches undervalue or fail to value non-monetary activities, such as ecosystem resilience and the non-productive work undertaken, traditionally, by women. ${ }^{101}$ They maintain that promoting a green economy promotes a worldview that ignores the 'totality of human active labour and natural resources'. ${ }^{102}$ Mary Mellor argues that the current economic paradigm is representative of a masculine-experience (ME) economy. She states that this economy has separated itself from the 'ecological and social framework of human being in its widest sense' ${ }^{103}$ In the ME economy, the ideal is presented as the 'economic man' who bears no responsibility for the domestic sphere, nor for the life-cycle of the goods and services he consumes, 'any more than he questions the source of the air he breaths or the disposal of his excreta'. ${ }^{104}$ This results in an economy that is disembodied both through not accommodating the life cycle of the human body in a money-valued economy and by disembedding the economy from the Earth's ecosystems. Not only is a ME-economy constrained by the local ecosystem cycles, it 'dumps its waste on poor, marginalised communities'. ${ }^{105}$ These lead to externalities that erode marginalised communities' well-being, and in particular women's material well-being by increasing the time that they spend in domestic activities. ${ }^{106}$ Therefore, the integration of economic growth strategies into the Outcome Document may continue to devalue and marginalise the unrecognised and often invisible work undertaken by women.

In sum, the interventions and statements made by the WMG and IPMG over the course of the preparatory process for the UNCSD emphasise their concerns that a green economy may continue to devalue and marginalise women and other excluded communities. They have raised concerns over the affirmation that sustained economic growth is seen as the bedrock of sustainable development. They noted that this affirmation continues the devaluation of women's domestic work. ${ }^{107}$ These criticisms go to the heart of the current conceptualisation of

\footnotetext{
${ }^{101}$ Mary Mellor, 'Ecofeminist Political Economy and the Politics of Money' in Ariel Salleh (ed), Eco-Sufficiency and Global Justice (Pluto Press 2009), 253-254; Anne Orford, 'Contesting Globalization: A Feminist Perspective on the Future of Human Rights' (1998) 8(2) Transnational Law \& Contemporary Problems 171, 171-173; Susan Moller Okin, 'Poverty, Well-being and Gender: What counts, Who's Heard?' (2003) 31(3) Philosophy \& Public Affairs 280, 285.

${ }^{102}$ Mary Mellor, 'Ecofeminist Political Economy' (2006) 1(1/2) International Journal of Green Economics 139, 140.

${ }^{103}$ Mellor, 'Ecofeminist Political Economy and the Politics of Money', above n 101, 254.

${ }^{104}$ Ibid.

105 Ibid.

${ }^{106}$ Moller Okin, above n 101, 285.

${ }^{107}$ Mellor, 'Ecofeminist Political Economy', above n 102, 141;
} 
(C) Wilkinson K, 'Is this the Future We Want? An Ecofeminist Comment on the UN Conference on Sustainable Development Outcome Document' in K Rubenstein and KG Young (eds), The Public Law of Gender: From the Local to the Global (Cambridge University Press 2016).

DOI: https://doi.org/10.1017/cbo9781316481493.024

the green economy and were consistently raised over the course of the preparatory process. Not only do they have a profound effect on how humanity perceives human/nonhuman relationships, but the way that the green economy is able to support and empower women in order to achieve gender equality that moves beyond the structural, ideological and material inequalities that maintain the devalued representation of women and nonhuman nature in the dominant social paradigm. In the following discussion, I will examine the extent to which the concerns raised by the Major Groups have been addressed and incorporated in the Outcome Document.

\section{The Green Economy and gender equality in the Outcome Document}

The Outcome Document incorporates a green economy in the context of sustainable development and poverty eradication and pays particular attention to the empowerment of women in this approach. ${ }^{108}$ In the following discussion, I will examine the extent to which the Document has moved beyond assumptions integrated in the dominant social paradigm in its inclusion of gender equality. I will focus on the integration of women and marginalised others into the green economy through job creation strategies, the integration of the 'ecosystem services' in the context of natural resource management and the emphasis on productive growth.

The Outcome Document contains a number of provisions endeavouring to support and enhance the welfare of women and marginalised groups through green economic policies. ${ }^{109}$ It affirms that a green economy mobilises the 'full potential' and 'equal contribution' of men and women and drives 'sustained, inclusive and equitable economic growth and job creation, particularly for women, youth and the poor. ${ }^{110}$ These statements suggest that the Outcome Document considers a green economy to be a strategy that supports and empowers women by integrating them into the economy.

However, an ecofeminist analysis of these justifications suggests that the Outcome Document may continue to devalue and denigrate the non-productive contributions that women and other marginalised groups make in the informal economy. Ecofeminists argue that neoliberal

See also CEDAW , above $\mathrm{n}$ 9, preamble 'Bearing in mind the great contribution of women to the welfare of the family and to the development of society, so far not fully recognized' and art 14; Beijing Declaration, above n 9, Annex II, [153], [155].

${ }^{108}$ The Future We Want, above n 23, [58(j)-(k)], [62] [64].

${ }^{109}$ Ibid, [58(k)].

${ }^{110}$ Ibid, [58(1)], [62]. 
(C) Wilkinson K, 'Is this the Future We Want? An Ecofeminist Comment on the UN Conference on Sustainable Development Outcome Document' in K Rubenstein and KG Young (eds), The Public Law of Gender: From the Local to the Global (Cambridge University Press 2016).

DOI: https://doi.org/10.1017/cbo9781316481493.024

political economy places significant emphasis separation, efficiency, and the neutrality of markets. ${ }^{111}$ In this paradigm, the 'self' is valued when it is efficient and rational. ${ }^{112}$ This valorisation of the rational and efficient in the economy denies the 'ecological embeddedness of human life' and legitimises the exploitation of nature because humanity is seen as distant and separate from it. ${ }^{113}$ Therefore, rationalist ideologies included in dominant economic systems deny the embeddedness of human realities in ecological realities. ${ }^{114}$ This means that work maintaining the body through the cycle of life is devalued because it is repetitive, local, necessary, communal and embedded in the local ecosystem. ${ }^{115}$ Therefore, this work is situated outside the value economy, while simultaneously providing the foundations for that economy to exist. ${ }^{116}$ This means that women's interaction with the local environment has been ignored and excluded from development planning with the result that women bear significant costs to their material well-being. ${ }^{117}$

Even when the Document recognises the informal and unpaid work performed by women, this acknowledgement is qualified by committing to work toward access to education. ${ }^{118}$ This in itself may be seen as a positive step because it recognises that women, due to their informal and often devalued roles, are unable to continue education. However, it also qualifies the 'value' of this work by implying that once women are educated, not only will they continue to undertake these informal tasks, they will also be expected to contribute to the formal, productive economy. This approach indicates that the international community has not yet acknowledged the significant contributions made by women in the domestic and private sphere and that the version of a green economy envisioned in the Document maintains this devaluation/separation between the productive, economic sphere and the reproductive, private

\footnotetext{
111 Julie A Nelson, Economics for Humans (University of Chicago Press, 2006), 24; Terry L. Anderson and Donald R. Leal, Free Market Environmentalism (Palgrave Macmillan Ltd, 2001), 6-8.

112 Jeanna Moyer, 'Why Kant and Ecofeminism Don't Mix' (2001) 16(3) Hypatia 79, 81; Plumwood, Feminism and the Mastery of Nature, above n 30, 49-50.

${ }_{113}$ Plumwood, Environmental Culture, above n 29, 98.

${ }^{114}$ Chris J Cuomo, 'On Ecofeminist Philosophy' (2002) 7(2) Ethics and the Environment 1, 1; see also Mellor, Feminism \& Ecology, above n 30; Plumwood, Feminism and the Mastery of Nature, above n 30; Plumwood, Environmental Culture, above n 29.

115 Mellor, 'Ecofeminist Political Economy', above n 102, 141-142; Mary Mellor, 'Feminism and Environmental Ethics: A Materialist Perspective' (2000) 5(1) Ethics and the Environment 107, 111.

${ }^{116}$ Julie A Nelson, 'Value as Rationality: Feminist, Pragmatist, and Process Thought Meet Economics ' (2001) 15(2) Journal of Speculative Philosophy 137, 138.

${ }^{117}$ Bharati Sadasivam, 'The Impact of Structural Adjustment on Women: A Governance and Human Rights Agenda' (1997) 19(3) Human Rights Quarterly 630; Moller Okin, above n 101, 284-286.

${ }^{118}$ The Future We Want, above n 23, [153].
} 
(C) Wilkinson K, 'Is this the Future We Want? An Ecofeminist Comment on the UN Conference on Sustainable Development Outcome Document' in K Rubenstein and KG Young (eds), The Public Law of Gender: From the Local to the Global (Cambridge University Press 2016).

DOI: https://doi.org/10.1017/cbo9781316481493.024

sphere. ${ }^{119}$ Therefore, without actively engaging with these ideological and structural assumptions that inform the dominant economic paradigms, including the green economy, the extent to which the concept may enable gender equality, is limited.

Therefore, the extent to which the Outcome Document and its affirmation of a green economy has enabled a revaluation of the dominant social paradigm and its deeply gendered assumptions, has been somewhat limited. While there are a number of references to supporting the equal participation by both sexes in the green economy and ensuring that women are educated in order to obtain green jobs, there has been little engagement with the way in which the dominant, neo-liberal economic assumptions maintain the structural and ideological subordination and devaluation of women's work, while also creating significant material barriers for women to overcome in order to perform their work. This suggests that the Outcome Document may not have revalued the underlying and inherent gendered inequalities in the dominant economic system but have effectively 'green washed' ${ }^{\prime 20}$ the current paradigm.

\section{Conclusion}

This chapter set out to examine the preparatory process and the resulting Outcome Document of the UN Conference for Sustainable Development (2012) and the extent to which it may have addressed the gendered way in which the dominant social paradigm devalues and subordinates traditionally excluded groups, such as women, ideologically, structurally and materially. In this examination I concluded that the Outcome Document has substantially reaffirmed a liberal understanding to gender equality in which women are assimilated into the existing governance structures. The Document consistently affirmed and supported the full and equal participation by women in the policy development and decision-making concerning sustainable development. In this way, the Document may be seen as a success because it recognises and addresses the exclusion and marginalisation of women within institutional governance structures.

However, an ecofeminist critique of the Document suggests that there are still many barriers to the full and equal participation by women in environmental issues. These relate to those ideological and structural assumptions that inform the dominant social paradigm within the concept of sustainable development. Therefore, this Document also suggests that there has

\footnotetext{
119 WMG, From the Future We Want to The Future We Need, above n 14, 1-2.

${ }^{120}$ Ibid, 2.
} 
(C) Wilkinson K, 'Is this the Future We Want? An Ecofeminist Comment on the UN Conference on Sustainable Development Outcome Document' in K Rubenstein and KG Young (eds), The Public Law of Gender: From the Local to the Global (Cambridge University Press 2016).

DOI: https://doi.org/10.1017/cbo9781316481493.024

been a project of assimilation where women and traditionally excluded groups are incorporated within institutions and paradigms that help maintain ideologies that continue to devalue and denigrate their contributions.

This is particularly seen in the analysis of the green economy introduced by the Outcome Document which maintains separation and distance between humanity and non-human nature, continues to devalue the non-productive work by women and often has significant material impacts on the livelihoods and cultural heritage of traditionally excluded peoples, all for the commitment to sustained economic growth.

Without addressing the inherently gendered assumptions within the dominant social paradigm, most attempts to integrate gender equality in sustainable development projects and in the development of a new economic paradigm, will simply maintain the status quo and perpetuate the ideologies that continue to affect women at a structural and material level. Not only does this have a profound effect on the ability to further gender equality, it raises significant questions about the current drive to renew political commitment to sustainable development and its ability to ensure the preservation of an Earth in which all peoples are able to live, equally. 